\title{
Mapping Soil Erosion Sensitive Areas in Organic Matter Amended Soil Associations in the Ntabelanga area, Eastern Cape Province, South Africa
}

\author{
${ }^{* 1,2}$ COSMAS PARWADA; ${ }^{1,3}$ JOHAN VAN TOL
}

\author{
${ }^{1}$ Department of Agronomy, University of Fort Hare, P.BagX1314 Alice 5700, South Africa \\ ${ }^{2}$ Department of Horticulture, Women's University in Africa, P.O. Box 1175, Marondera, Zimbabwe \\ ${ }^{3}$ Department of Soil-and Crop-and Climate Sciences, University of the Free State, Bloemfontein, South Africa \\ *Corresponding Author Email: cparwada@gmail.com
}

\begin{abstract}
The study aims to map areas sensitive to erosion by water and rainfall erosivity after addition of organic matter (OM) in highly unstable soils. A soil association map was created using digital soil mapping methodology. Soil samples from six soil associations were incubated and analysed for several soil erodibility measures and inferred to the soil association map. Soil stabilization against soil erosion by use of OM was evaluated for 30 weeks under two simulated rainstorms, intermittent rainstorms (IR) and single rainstorm (SR). Rainfall erosivity (R-factor) was calculated from the duration of a rainstorm and the total amount of rainfall received under rainfall simulations. Erodibility factor (K-factor) was estimated using the soil OM content and texture. Largest area $(40 \%)$ was covered by shallow soils and $\mathrm{K}$-factor range of 0.0693-0.0778 tha.hha ${ }^{-1} \mathrm{MJ}^{-1} \mathrm{~mm}^{-1}$. Largest (60.2\%) area had a structural stability index of 0.8 and $42.7 \%$ of the area was covered by a dispersion ratio value range of $0.65-0.70$. The area size with erosion rates of $>15 \mathrm{t} / \mathrm{ha} / \mathrm{yr}$ was drastically reduced from 1 to 8 weeks after OM application thereafter gradually increased under both IR and SR. Soil erosion rates of $<5 \mathrm{t}^{-1} \mathrm{ha}^{-1} \mathrm{yr}^{-1}$ and $>15 \mathrm{t}^{-1} \mathrm{ha}^{-1} \mathrm{yr}^{-1}$ were most and least observed respectively under both storms. R-factor was higher under IR than SR and the smallest areas with soil erosion rates of $>15 \mathrm{t}^{-1} \mathrm{ha}^{-1} \mathrm{yr}^{-1}$ contributed most to the lost soil. Organic matter confers soil resistance to erosion up to a certain period before losing its effectiveness. The study provided first assessment of erosion dynamics, basis for identifying conservation priorities which may be applicable in similar areas.
\end{abstract}

DOI: https://dx.doi.org/10.4314/jasem.v24i9.29

Copyright: Copyright $(\mathbb{C} 2020$ Parwada and Van Tol. This is an open access article distributed under the Creative Commons Attribution License (CCL), which permits unrestricted use, distribution, and reproduction in any medium, provided the original work is properly cited.

Dates: Received: 10 August 2020; Revised: 16 September 2020; Accepted: 22 September 2020

Keywords: Erosivity, planning, rainstorm, soil conservation, soil degradation

Accelerated soil erosion is a serious global problem that not only threatens the sustainability of agriculture but also infrastructural development (Parwada and Van Tol, 2016). The soil erosion and related degradation of land resources are highly significant spatio-temporal phenomena (Van Zijl et al., 2014). The rates of soil erosion are as a result of the interactive effects of erodibility and erosivity factors in an area (Cheng et al., 2008). In areas experiencing low and light rainfall, the rates of soil loss are majorly influenced by the soil erodibility factors such as soil organic carbon (SOC) content, texture, clay content and soil structure (Laker, 2004). The soil erodibility and erosivity factors determine the rate and form of erosion at a spatio-temporal scale. Spatial and quantitative information on soil erosion contributes significantly to the planning for soil conservation, erosion control, and management of the watershed environments (Cheng et al., 2008). Suggesting that sustainable land management practices are necessary to preserve the potential of land and protect surface water bodies from siltation. In South Africa, the soil erosion is a critical land degradation issue in South
Africa and more than $70 \%$ of the country is affected by varying intensities of soil erosion (Le Roux et al., 2008). Eroded soil material leads to siltation of reservoirs as well as an increase in pollution due to suspended sediments concentrations in streams which affect water use and ecosystem health (Parwada and Van Tol, 2016). Regardless of such soil erosion background, the government of South Africa (SA) under the Department of Water Affairs (DWA) has proposed to construct a multipurpose dam along the Tsitsa River in the Ntabelanga area, EC (DWA, 2013). Soil erosion data characterized soils in the area as highly unstable, easily erodible and there are high rates of soil erosion (Parwada and Van Tol, 2016). In the early 1980s, soil erosion loss rates in SA was estimated to vary between 300 and $400 \mathrm{t}$ per annum, or some 10 t per capita per annum (Le Roux et al., 2008). Such estimates are gross generalization and hence of limited value, especially given the large range of present-day erosion rates cited in the literature (Laker, 2004). For SA alone, these rates vary from as low as $0.5 \mathrm{t}^{-1} \mathrm{ha}^{-1}$ year $^{-1}$ to more than $110 \mathrm{t}^{-1} \mathrm{ha}^{-1}$ year $^{-1}$ (Le Roux et al., 2008). Considering this general 
information on SA soil loss rates, it may be difficult to relate the rates to a specific area of interest. It is therefore critical to delineate soils according to their sensitivity to erosion for easy land managements. In the Eastern Cape (EC) Province, particularly in the communal lands, experienced high rates of erosion due to low organic carbon content $(<2 \%)$ in the soils (Laker, 2004). The high rates of erosion could shorten the dam lifespan through siltation if unchecked (Parwada and Van Tol, 2016) therefore stabilizing the soils against erosion was a priority. Effective control of soil erosion is still a challenge in the EC province. Traditional soil conservation strategies such as stone terracing, contour walls, gabions and potholing have failed to address the soil erosion problems as evidenced by water-damaged stone terraces in most parts of EC province (Laker, 2004). Alternative strategies like stabilization of soil structure through the addition of organic matter can be a solution. Currently, there is a large question mark on whether or not the traditional measures are helping curb erosion or rather enhancing it. Before prevention of soil erosion or remediation can be undertaken, the spatial extent of the problem should be estimated again, one has to understand the forms and scale of soil erosion operating in an area (Van Tol et al., 2014). The largest scale is gully erosion, and erosion should be controlled before it reaches the point of gullies, as erosion rates escalate as soon as gullies form and it is much more difficult to stop gully erosion than the other forms of erosion. Gullies can form by two different mechanisms, overland flow and piping (Van Zijl et al., 2014). When one understands how the different mechanisms operate, it is clear to see that different mitigation strategies must exist for the different mechanisms of gully formation (Van Tol et al., 2014). In this regards, it is advisable to closely monitor the soil erosion process and rates of soil loss even after soil amelioration. The amelioration processes are developed and applied following prioritization and landscape planning. Prioritization plays a key role in identifying areas that require attention (Van Zijl et al., 2014).

Many approaches for delineation sensitive areas to soil erosion by water are available in the literature (Afifi and $\mathrm{Gad}, 2011$ ). Integration and application of statistical approaches and geographic information system (GIS) techniques, as well as quantitative models to assess and predict soil erosion are also available (Van Zijl et al., 2014; Afifi and Gad, 2011). However, these erosion models are generally developed for a specific region over small scales, making their application in areas for which they have not been tested and validated rather restricted (Van Zijl et al., 2014; Afifi and Gad, 2011). Alternatively, erosion risk mapping based on quantitative data integration provides a better option for specific areas where the data have been obtained in erosion assessment (Van Zijl et al., 2014). Thus, in many parts of the world, soil erosion risk mapping is used for identifying high erosion areas where resources of soil water conservation programs can be effectively concentrated (Van Tol et al., 2014).Often, a quantitative assessment is needed to infer the extent and magnitude of soil erosion problems so that effective management strategies can be compiled. But the complexity of the variables makes precise estimation of erosion difficult. The quantification of soil erosion currently is a process with complex and unstructured decisions. Ideally, an integrated and systematic approach taking into considerations of sitespecific soil properties should be implemented. Most of the models are established based on either empirical approaches or statistical methods and significant uncertainty of predictive simulations could result (Afifi and Gad, 2011). There is a need to identify key components of erosion processes for sustainable environmental management and planning. Particularly, the need to identify where the main erosion areas are located, and which areas are impacted by severe soil loss (Van Zijl et al., 2014). If these areas are properly identified, management and mitigation can become effective. Hazard assessment is also required to plan new developments with limited erosion impacts. However, both mapping of active erosion and the assessment of hazard at a large scale is time-consuming, costly and rarely updated.

Assessment and management of impacts of erosion processes can only be done if data exist regarding the soil erodibility characteristics (Van Tol et al., 2014). In some cases, the available data is difficult to interpret for effective planning (Afifi and Gad, 2011) hence need to be simplified and presented in easily interpreted ways by land managers e.g by soil maps. However, there are few inventory maps drawn using the soil erosion indices and the response of the soil to erosion after amelioration indicating erosion sensitive areas.

Currently, most soil erosion maps are drawn from soil data collected at coarser scales, therefore, be ineffective for managing soil erosion (Parwada and Van Tol, 2016). The soil erosion maps ignore causes of and control measures for soil erosion at soil aggregate level (soil micro scale-level). We hypothesized that soil physical properties and soil organic carbon (SOC) influenced the soil loss rates of the soil associations in the Ntabelanga area. Therefore, this study aims to delineate the study area according to rates of soil loss under two simulated rainstorms after 
increasing the SOC $(>2 \%)$ and selected soil erodibility indices.

\section{MATERIALS AND METHODS}

Description of the study area: The study was conducted at a proposed Ntabelanga dam site in the EC Province located about $380 \mathrm{~km}$ south-east of University of Fort Hare (UFH), South Africa. The dam site is characterized by highly unstable soils and prone to high soil erosion rates. Stabilizing the soils and controlling the soil erosion rates will reduce sedimentation and prolong the dam life-span. The area is located between $31^{\circ} 7^{\prime} 35.9^{\prime \prime} \mathrm{S}$ and $28^{\circ} 40^{\prime} 30.6^{\prime \prime} \mathrm{E}$ and falls within the South Eastern Uplands Aquatic Ecoregion and the Mzimvubu to Kieskamma Management Area (Department of Water Affairs, 2013). This work followed on studies of Van Tol et al. (2014). In these studies, the soils of land type Db344 were mapped in some detail.

Based on these maps, representative areas of soil associations were identified and selected for soil sampling and incubation. Although this method includes only 30 sampling locations, these soils are representative of the majority of Db344 (Van Tol et al., 2014). The Db334 refers to an area where duplex soils with a non-red B horizon cover more than 50\% of the land area (Land Type Survey Staff, 1972 2006). The dominant soils in these land types are, therefore, marked by soils with textural differences between A and B horizons. Finer textured B horizons limit the suitability for agricultural production on these soils. The increase in texture is generally associated with a decrease in hydraulic conductivity and the formation of perched water tables on the $\mathrm{A} / \mathrm{B}$ horizon can result. These soils are, therefore, generally susceptible erosion, especially in this land type.

The study area is largely $\left(74.17 \mathrm{~km}^{2}\right)$ covered by the land type Db334 (Figure 1). This land type was selected to identify erosion sensitive areas basing predominantly on surface colours and its surface that have been exposed by either erosion or by cultivation (Van Tol et al., 2014). The initial soil characterization in the area was done by Parwada and Van Tol, (2016). The soil incubation was done in the soil physics laboratory at the UFH, South Africa.

Soil sampling and analysis: To map the soils, randomly selected sampling points generated from a geographical position system (GPS) were identified from a proposed dam catchment. Then soil samples were taken from naturally existing soil horizon profiles at the 30 points. The soils were described and classified into soil forms using the South African Soil
Classification System (Soil Classification Working Group (1991) (Table 1).

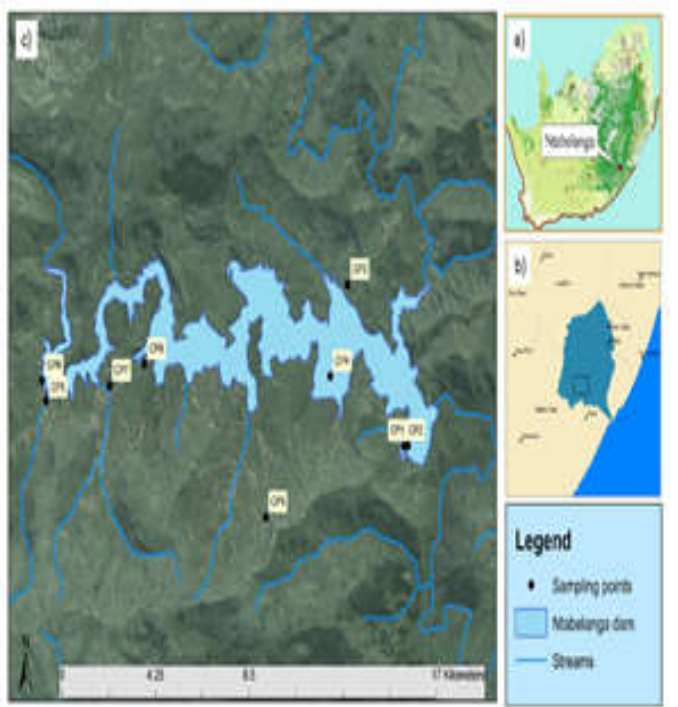

Fig 1. Location of the Ntabelanga area in the Eastern Cape Province, South Africa ( $a$ and $b$ ) and the soil sampling points (c)

The soil forms were then grouped together into six soil associations, which have the same functionality in terms of soil loss rates (Table 2). Soil erosion sensitive mapping was not done for the whole dam catchment but only on the areas with highly unstable soils. A soil association map was created using digital soil mapping techniques as described by Van Zijl et al, (2014).

Briefly a Conditioned Latin hypercube sampling (cLHS) (Minasny and McBratney, 2006) was used to pre-determine 30 field observation positions. The cLHS method determines observations positions which represent the entire attribute space. Altitude, aspect, profile curvature, planform curvature, topographical wetness index, slope and multiresolution valley bottom floor (MRVBF) were the co-variates used. Another 57 observations were made at the discretion of the soil surveyors whilst in the field.

The combination of the two observation point determination methods ensures that the entire attribute space is observed, whilst also allowing the soil surveyor to investigate specific soil terrain relationships. Soils were classified according to the Soil Classification Working Group (1991), and later grouped into soil associations (Table 1) based on their susceptibility to soil erosion (Van Zijl et al., 2014). To create the soil association map, 64 of the observations were used to create a multinomial linear regression algorithm in $\mathrm{R}$. The remaining 23 observations were used as an independent validation data set. 
Table 1. Descriptions of the mapped soil associations

\begin{tabular}{|c|c|c|c|}
\hline Soil Association & $\begin{array}{l}\text { South African } \\
\text { Soil Form* }\end{array}$ & $\begin{array}{l}\text { WRB Reference } \\
\text { Group*** }\end{array}$ & $\begin{array}{l}\text { Defining } \\
\text { characteristic }\end{array}$ \\
\hline \multirow[t]{4}{*}{ Shallow } & Glenrosa & Leptosols & \multirow{4}{*}{$\begin{array}{l}\text { Rock or rocky horizon } \\
\text { such as Lithocutanic B } \\
\text { as a second horizon }\end{array}$} \\
\hline & Mayo & Luvic leptosols & \\
\hline & Mispah & Leptosols & \\
\hline & Cartref & Cambisols & \\
\hline \multirow[t]{9}{*}{ Apedal } & Hutton & Ochric Ferralsols & \multirow[t]{9}{*}{ Apedal subsoil horizon } \\
\hline & Avalon & Acrisols & \\
\hline & Longlands & Plithosols & \\
\hline & Bloemdal & Cambisols & \\
\hline & Westleigh & Arenosols & \\
\hline & Shortlands & Chromic nitisols & \\
\hline & Oakleaf & Luvisols/Cambisols & \\
\hline & Tukulu & Gleyic luvisols & \\
\hline & Vilafontes & Lixosols & \\
\hline \multirow[t]{3}{*}{ Semi-Duplex } & Valsrivier & Chromic luvisols & \multirow{5}{*}{$\begin{array}{l}\text { Moderate degree of } \\
\text { structure in the subsoil } \\
\text { horizon } \\
\text { Sandy topsoil on a } \\
\text { clayey prismacutanic B } \\
\text { subsoil horizon }\end{array}$} \\
\hline & Swartland & Leptic cambisols & \\
\hline & Sepane & Luvisols & \\
\hline \multirow[t]{2}{*}{ Duplex } & Kroonstad & Stagnosols & \\
\hline & Sterkspruit & Haplic cambisols & \\
\hline \multirow[t]{2}{*}{ Melanic } & Bonheim & Phaozems & \\
\hline & Willowbrook & Umbrisols & \multirow{3}{*}{$\begin{array}{c}\text { Water logged subsoil } \\
\text { horizon }\end{array}$} \\
\hline \multirow[t]{2}{*}{ Wet } & Dundee & Fluvisols & \\
\hline & Katspruit & Gleysols & \\
\hline
\end{tabular}

Nine sampling points per area of soil association were randomly selected from global positioning systems (GPS) generated coordinates on the soil association map. Soil samples were taken according to naturally occurring soil horizons in the areas of soil associations (Table 1). The soils were analyzed for primary particle size distribution and total soil organic carbon was determined as described by Parwada and Van Tol (2019). Then the K-factor was obtained using a modified soil erodibility nomograph as proposed by Parwada and Van Tol (2016). The algebraic approximation of the nomograph included five parameters (texture, organic matter content, coarse fragments, surface structure and permeability) (Renard et al., 1997), soil structural index (SI) estimated according to Reynolds et al. (2007) and the dispersion ratio (DR) calculated according to Igwe et al. (1995). Soil loss by splash erosion was obtained using a modified procedure proposed by Parwada and Van Tol (2019). Briefly, a rainfall simulator with 49 capillary tubes was used to uniformly apply raindrops of $5.9 \mathrm{~mm}$ in diameter on the soil. The splash cups containing the soil were slowly pre-wetted from the bottom with tap water until saturated and then placed under the rainfall simulator. The samples were subjected to simulated rainfall at $360 \mathrm{~mm} \mathrm{~h}^{-1}$. Rainfall was applied either as an 8 min single rainstorm (SR) or $4 \times 2$ min intermittent rainstorms (IR) separated by a $72 \mathrm{~h}$ drying period. The rainfall patterns and drying period of the treatments were adopted to mimic the predicted climate scenarios. The high-intensity rainfall was used to compensate for the short falling distance of $0.4 \mathrm{~m}$, of each simulated raindrop and the resulting low volume-specific kinetic energy of the applied shower as suggested by Martin et al. (2010). The timespecific energy of the simulated rain was $1440{\mathrm{~J} . \mathrm{m}^{-}}^{-}$ ${ }^{2} . \mathrm{hr}^{-1}$. Natural rainfall events with this time-specific kinetic energy approximate natural rainfall intensities of about $60 \mathrm{~mm} \cdot \mathrm{h}^{-1}$ (Martin et al., 2010). Splashed sediment was washed out of the plate into a jar, ovendried at $105{ }^{\circ} \mathrm{C}$ for 24 hours and weighed. Then the estimated total soil loss per rainstorm was calculated as follows:

Totalestimatedoilloss $(t / h a)=\sum\left(A_{S A}\right) \times \frac{D}{100 \times A}$

Where $A_{S A}$ is the total area covered by a soil association $\left(\mathrm{km}^{2}\right), D$ is the measured sediments from the splash plate in grams either from IR or SR simulated rainstorms and $A$ is the surface area of the splash cup.

Rainfall factor $(R)$ : Rainfall factor $(\mathrm{R})$ is, an index used as a measure of the erosive force of a specific rainfall.

It is a function of intensity and duration of the rainfall and can be computed from the single storm (SR) or intermittent rainstorms (IR) to include cumulative erosivity from any time period (Parwada and Van Tol., 2019). Splash erosion is the dominant type of erosion in barren soil surfaces. The simulated rainstorms as explained above were used for calculating the $R$-factor 
using the modified relationship developed by Arnoldus (1980):

$$
R=\sum_{i=1}^{n} 1.735 \times 10\left(1.5 \log _{10}\left(\frac{P_{i}^{2}}{P}\right)-0.08188\right)
$$

Where $R$ is the rainfall erosivity factor (MJ mm ha ${ }^{-1} h^{-}$ $\left.{ }^{1} \mathrm{y}^{-1}\right), P_{i}$ is the amount of rainfall per minute $(\mathrm{mm}), P$ is the total rainfall in 8 minutes $(\mathrm{mm})$ and $n$ is the number of rainstorms.

Soil incubation: The soils were sieved $(<0.25 \mathrm{~mm})$ and amended with two different sources of organic matter (OM) to raise soil organic carbon (SOC) content of the soils to $>2 \%$. The used OM sources were Vachellia karroo leaves (high quality) and Zea mays stover (low quality) (Parwada and Van Tol, 2019). The soil-organic matter mixture was to constitute at least $2 \%$ SOC (minimum threshold SOC content for aggregate stability) (Kay and Angers 2000) because the soil associations were low $(<2 \%)$ in SOC content (Parwada and Van Tol, 2016). A $600 \mathrm{~g}$ of each amended soil was then put in $1000-\mathrm{mL}$ jars and incubated at a moisture content equivalent to $60 \%$ water holding capacity and a temperature of $25{ }^{\circ} \mathrm{C}$ for 30 weeks. In the incubator, jars were arranged as a $7 \times$ 3 factorial laid in a completely randomized design (CRD) with three replicates. A subsample was taken from each jar at 1, 3, 8, 14, 23 and 30 weeks during incubation and analyzed for soil loss by splash erosion under two simulated rainfall storms, intermittent rainstorms (IR) and single rainstorm (SR).

Data analysis: Analysis of variance (ANOVA) test was run to compare the soil loss by splash under the two simulated rainstorms. Means were separated using the Tukey test $(\mathrm{p}<0.05)$. All data were analyzed using JMP version 11.0.0 statistical software.

\section{RESULTS AND DISCUSSION}

Soil Maps: The soil association map (Figure 2) achieved a point accuracy of $65 \%$ and a Kappa value of 0.57 , indicating a moderate agreement with reality. These values are slightly lower than comparable digital soil mapping maps created in southern Africa, such as the $73 \%$ point accuracy van Zijl et al. (2014) obtained for 4001 ha in the Kruger National Park, and the $80 \%$ point accuracy obtained by Van Zijl et al. (2014) for 10970 ha near Gurue, Mozambique. The accuracy can be attributed to the lower sampling density for this project ( 85 ha per observation) when compared to the other mentioned projects (53 and 35 ha per observation for Mozambique and Kruger National Park, respectively). The $65 \%$ point accuracy is acceptable for a soil map, as it compares well with the $65 \%$ accuracy determined for conventional soil maps by Minasny and Mcbratney (2006).

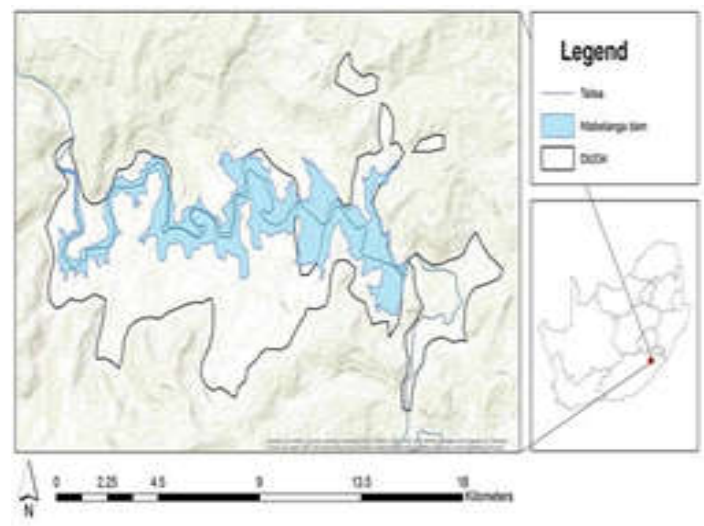

Fig 2. The proposed dam footprint, dominant stream and land type (Db334) in the study area

Table 2. Distribution of K-factors by percentage area covered in the Ntabelanga area

\begin{tabular}{|c|c|c|c|}
\hline $\begin{array}{l}\text { Soil loss } \\
\text { class }\end{array}$ & $\begin{array}{l}\text { K-factor (t } \\
\text { ha h ha }^{-1} \mathbf{M J}^{-} \\
\left.{ }^{1} \mathbf{m m}^{-1}\right)\end{array}$ & $\begin{array}{l}\text { Soil } \\
\text { association }\end{array}$ & $\begin{array}{l}\% \text { of } \\
\text { area }\end{array}$ \\
\hline \multirow{6}{*}{ Moderate } & \multirow{6}{*}{$\leq 0.0471$} & Shallow & 4.2 \\
\hline & & Apedal & 0.2 \\
\hline & & Semi-duplex & 1.2 \\
\hline & & Melanic & 0.7 \\
\hline & & Duplex & 0.9 \\
\hline & & Wet & 1.0 \\
\hline \multirow{6}{*}{ High } & \multirow{6}{*}{$\begin{array}{l}0.0471- \\
0.0596\end{array}$} & Semi-duplex & 7.0 \\
\hline & & Apedal & 3.8 \\
\hline & & Shallow & 7.6 \\
\hline & & Melanic & 0.8 \\
\hline & & Duplex & 3.4 \\
\hline & & Wet & 2.1 \\
\hline \multirow{6}{*}{$\begin{array}{l}\text { Very } \\
\text { high }\end{array}$} & \multirow{6}{*}{$\begin{array}{l}0.0596- \\
0.0693\end{array}$} & Shallow & 18.3 \\
\hline & & Melanic & 2.3 \\
\hline & & Duplex & 3.9 \\
\hline & & Wet & 1.4 \\
\hline & & Semi-duplex & 2.9 \\
\hline & & Apedal & 3.2 \\
\hline \multirow{6}{*}{$\begin{array}{l}\text { Very } \\
\text { high }\end{array}$} & \multirow{6}{*}{$\begin{array}{l}0.0693- \\
0.0778\end{array}$} & Apedal & 4.0 \\
\hline & & Duplex & 1.4 \\
\hline & & Semi-duplex & 1.3 \\
\hline & & Shallow & 6.1 \\
\hline & & Wet & 1.8 \\
\hline & & Melanic & 0.2 \\
\hline \multirow{6}{*}{$\begin{array}{l}\text { Very } \\
\text { high }\end{array}$} & \multirow{6}{*}{$\begin{array}{l}0.0778- \\
0.0876\end{array}$} & Shallow & 7.9 \\
\hline & & Duplex & 1.6 \\
\hline & & Wet & 0.8 \\
\hline & & Semi-duplex & 2.3 \\
\hline & & Melanic & 0.1 \\
\hline & & Apedal & 0.8 \\
\hline \multirow{6}{*}{$\begin{array}{l}\text { Very } \\
\text { high }\end{array}$} & \multirow{6}{*}{$\begin{array}{l}0.0876- \\
0.0962\end{array}$} & Wet & 1.9 \\
\hline & & Duplex & 2.8 \\
\hline & & Apedal & 0.1 \\
\hline & & Shallow & 2.3 \\
\hline & & Melanic & 0.3 \\
\hline & & Semi-duplex & 1.1 \\
\hline
\end{tabular}

Erodibility factor (K-factor): Generally, the K-factor ranges from $<0.010$ (very low), 0.010-0.020 (low), 
0.020-0.040 (moderate), $0.040-0.060$ (High) to $\geq$ 0.060 (very high) (Rosewell, 1993) and the higher the value the higher the rate of erosion. The Ntabelanga area has a considerable area $(67.1 \%)$ with erodibility factor values within the very high range (Table 2), suggesting that the area is prone to sheet and rill erosion therefore possible mitigatory measures should aim at providing ground cover and soil stabilization.

The K-factors of the surface horizons ranged from 0.0471 to $0.0982 \mathrm{Mg}^{-1} \mathrm{ha} .\left[\left(\mathrm{MJ}^{-1} \mathrm{ha}\right)\left(\mathrm{mm}^{-1} \mathrm{~h}\right)\right]^{-1}$ in the area. Most (40\%) parts of the area had a K-factor range value of $0.0693-0.0778 \mathrm{Mg}^{-1} \mathrm{ha} \cdot\left[\left(\mathrm{MJ}^{-1} \mathrm{ha}\right)\left(\mathrm{mm}^{-1} \mathrm{~h}\right)\right]^{-1}$ and smallest portions $(8 \%)$ with erodibility factor range value of $0.0596-0.0693 \mathrm{Mg}^{-1} \mathrm{ha} .\left[\left(\mathrm{MJ}^{-1} \mathrm{ha}\right)\left(\mathrm{mm}^{-}\right.\right.$ $\left.\left.{ }^{1} \mathrm{~h}\right)\right]^{-1}$ (Figure $3 \mathrm{~d}$ ). Only, $5 \%$ of the total area had a Kfactor range value of $0.0876-0.0962 \mathrm{Mg}^{-1}$ ha. $\left[\left(\mathrm{MJ}^{-}\right.\right.$ $\left.\left.{ }^{1} \mathrm{ha}\right)\left(\mathrm{mm}^{-1} \mathrm{~h}\right)\right]^{-1}$ contributed highest $(35.2 \%)$ to the eastimated soil loss in Ntabelanga. Soil associations with the highest $\mathrm{K}$-factor range value (0.0982-0.10) $\mathrm{Mg}^{-1}$ ha. $\left[\left(\mathrm{MJ}^{-1} \mathrm{ha}\right)\left(\mathrm{mm}^{-1} \mathrm{~h}\right)\right]^{-1}$ contributed the least $(5 \%)$ to eastimated total soil loss.

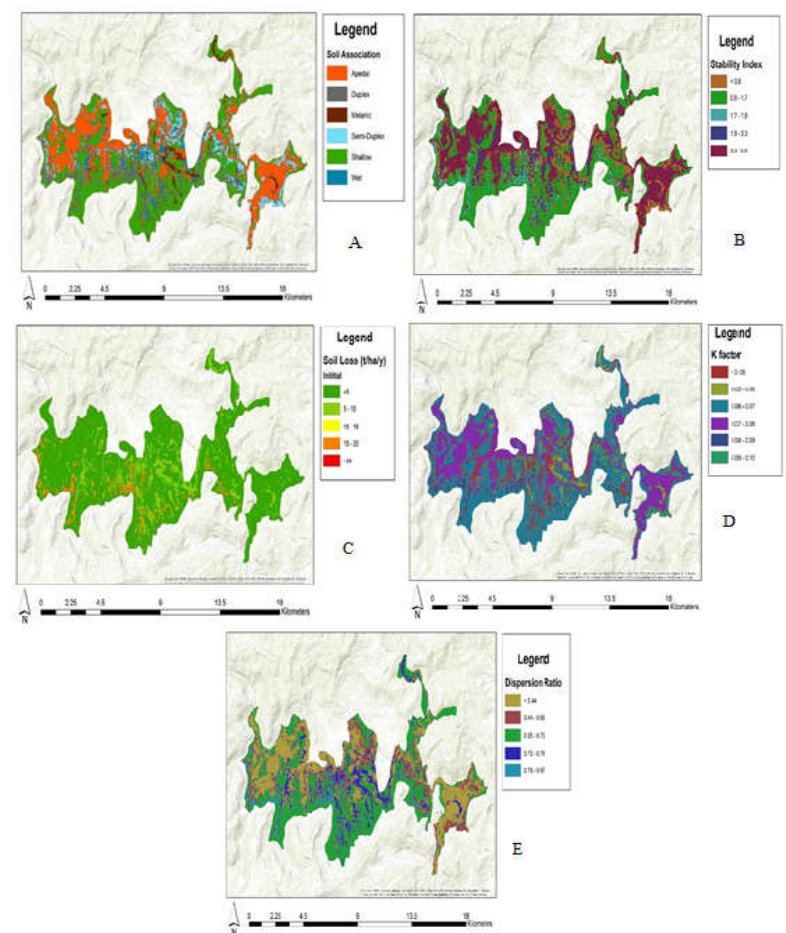

Fig 3. Spatial distribution of classified soil erosion risk zones using (a) soil associations, (b) stability index, (c) initial soil loss (t/ha/y), (d) K-factor and (e) dispersion ratio

It is worth noting that the $\mathrm{K}$-factor values derived in this study were based mainly on particle size distribution, soil organic carbon, and soil permeability rates. In reality, values for $\mathrm{K}$ - factor can be significantly altered by management (governed by the degree of soil disturbance, aggregation, organic matter content (Parwada and Van Tol, 2019). Therefore, the deviations from the norm due to a variation in land management were not considered in this study and can only be dealt with at a much finer scale were more detailed information is available.

Structural Stability index (SI): Reynolds et al. (2007) stated that $S I \leq 5 \%$ indicates structurally degraded soils due to extensive loss of organic carbon; $5<S I \leq$ $7 \%$ indicates a high risk of structural degradation due to insufficient organic carbon; $7<S I \leq 9 \%$ indicates a low risk of structural degradation and $>9 \%$ indicates sufficient SOC to maintain structural stability. All the soil associations in the Ntabelanga area had a SI value of less than $7 \%$ (Table 3), indicating a high risk of structural degradation, therefore the addition of organic matter is important to avoid further degradation.

Table 3. Distribution of structural stability index by percentage area covered in the Ntabelanga area

\begin{tabular}{|c|c|c|c|}
\hline Soil status & SI (\%) & $\begin{array}{l}\text { Soil } \\
\text { association }\end{array}$ & $\begin{array}{l}\% \text { of } \\
\text { area }\end{array}$ \\
\hline $\begin{array}{l}\text { Structurally } \\
\text { degraded }\end{array}$ & $\leq 0.8$ & $\begin{array}{l}\text { Shallow } \\
\text { Apedal } \\
\text { Duplex } \\
\text { Semi-duplex } \\
\text { Melanic } \\
\text { Wet }\end{array}$ & $\begin{array}{l}4.2 \\
1.5 \\
0.3 \\
0.9 \\
0.2 \\
2.5\end{array}$ \\
\hline $\begin{array}{l}\text { Structurally } \\
\text { degraded }\end{array}$ & $0.8-1.7$ & $\begin{array}{l}\text { Shallow } \\
\text { Apedal } \\
\text { Duplex } \\
\text { Semi-duplex } \\
\text { Melanic } \\
\text { Wet }\end{array}$ & $\begin{array}{l}30.6 \\
7.1 \\
9.7 \\
1.6 \\
0.9 \\
1.1 \\
\end{array}$ \\
\hline $\begin{array}{l}\text { Structurally } \\
\text { degraded }\end{array}$ & $1.7-1.9$ & $\begin{array}{l}\text { Shallow } \\
\text { Melanic } \\
\text { Duplex } \\
\text { Wet } \\
\text { Semi-duplex } \\
\text { Wet }\end{array}$ & $\begin{array}{l}9.4 \\
0.3 \\
2.1 \\
1.4 \\
1.8 \\
0.7\end{array}$ \\
\hline $\begin{array}{l}\text { Structurally } \\
\text { degraded }\end{array}$ & $1.9-3.3$ & $\begin{array}{l}\text { Apedal } \\
\text { Shallow } \\
\text { Duplex } \\
\text { Semi-duplex } \\
\text { Melanic } \\
\text { Wet }\end{array}$ & $\begin{array}{l}0.8 \\
4.0 \\
2.8 \\
1.4 \\
0.5 \\
1.1\end{array}$ \\
\hline $\begin{array}{l}\text { Structurally } \\
\text { degraded }\end{array}$ & $3.3-5.9$ & $\begin{array}{l}\text { Shallow } \\
\text { Duplex } \\
\text { Wet } \\
\text { Semi-duplex } \\
\text { Apedal } \\
\text { Melanic }\end{array}$ & $\begin{array}{l}6.5 \\
2.6 \\
0.8 \\
1.7 \\
0.8 \\
0.6\end{array}$ \\
\hline
\end{tabular}

Most (60.2\%) soil associations had structural stability index (SI) of $<0.8$ which contributed $48 \%$ of the estimated total soil loss (Figure $3 \mathrm{~b}$ and Table 3 ). An increase in SI resulted in a reduction in total soil loss, the highest range (1.9-3.3) SI value of the area covered 
$10.6 \%$ of the total area and contributed least (13.6\%) to total soil loss.

Dispersion ratio (DR): The dispersion ratios (DR) of the soil associations ranged from 0.05 to 0.97 , most $(42.7 \%)$ soil associations with DR range value of $0.07-$ 0.08 , accounted for the highest $(36.6 \%)$ of estimated total soil loss in Ntabelanga (Figure 3e). According to Hazelton and Murphy (2007), the minimum dispersion ratio fall above the slight category (6-30\%), the average and maximum dispersion in the very high ( $>$ $65 \%$ ) category. This result, therefore indicates that the soil associations are susceptible to erosion all of them. Smallest regions $(9.4 \%)$ of the total area had DR range values of 0.09-0.10, with a highest (59.2\%) contribution to the estimated soil loss (Figure 3e). The estimated soil loss was proportional to the area covered by the soil with a specific DR range value. Van Zijl et al. (2014) noted that soil dispersion is a dependent soil variable distinguishing the duplex soils from other soils so can be used in identifying areas with a high gully erosion potential. The conditions needed for piping to occur are soil with a dispersive nature, free water accumulating within the subsoil and an outlet for this free water (Van Tol et al., 2014). This suggests that the Ntabelanga area has a great potential for piping as a large area is covered by slight and maximum dispersion category (Figure 3e). Possible conservation practices must aim to increase aggregate stability at the soil surface, prevent clay dispersion and increase the infiltration rate of the subsurface horizons.

Initial rainfall erosivity prior incubation: Largest portions $(70 \%)$ of the area experienced predicted soil loss rate of $<5 \mathrm{t}^{-1} \mathrm{ha}^{-1} \mathrm{yr}^{-1}$ and smallest portions $(1.5 \%)$ experienced very high predicted erosion rates $\left(>20 \mathrm{t}^{-1}\right.$ $\mathrm{ha}^{-1} \mathrm{yr}^{-1}$ ) (Figure 3c). However, about $93 \%$ of the estimated total soil loss $\left(\mathrm{t}^{-1} \mathrm{ha}^{-1} \mathrm{yr}^{-1}\right)$ was from areas with erosion rates of above $5 \mathrm{t}^{-1} \mathrm{ha}^{-1} \mathrm{yr}^{-1}$ (Figure 3c).

Rainfall erosivity during incubation: Rainfall erosivity (MJ mm ha- ${ }^{-1} h^{-1} y^{-1}$ ) increased more under intermittent rainstorm (IR) than under single rainstorm (SR) from 1 to 30 weeks of incubation (Figure 4). Generally, the soil loss ( $\mathrm{t} / \mathrm{ha} / \mathrm{y})$ by flash erosion was significantly $(\mathrm{p}<0.05)$ higher in the OM unamended soils (control) than in OM amended soils as from 3 to 30 weeks of incubation (Figure 5). The higher rainfall erosivity noted under IR than SR could be due to the fact that the first rainstorm had broken the aggregate bonds and could not recover before the second storm. These results agree with Cheng et al. (2008) who observed that rainfall of maximum intensity for a short duration increased the splash erosion. Effects of organic matter on splash erosion during the 30 week incubation period for the soils are shown in Figures 6 to 9. In this the study, rainfall parameters were either SR or IR, therefore, the observed fluctuations in splash erosion rates were mainly caused by the interactions of soil surface characteristics and rainfall characteristics.

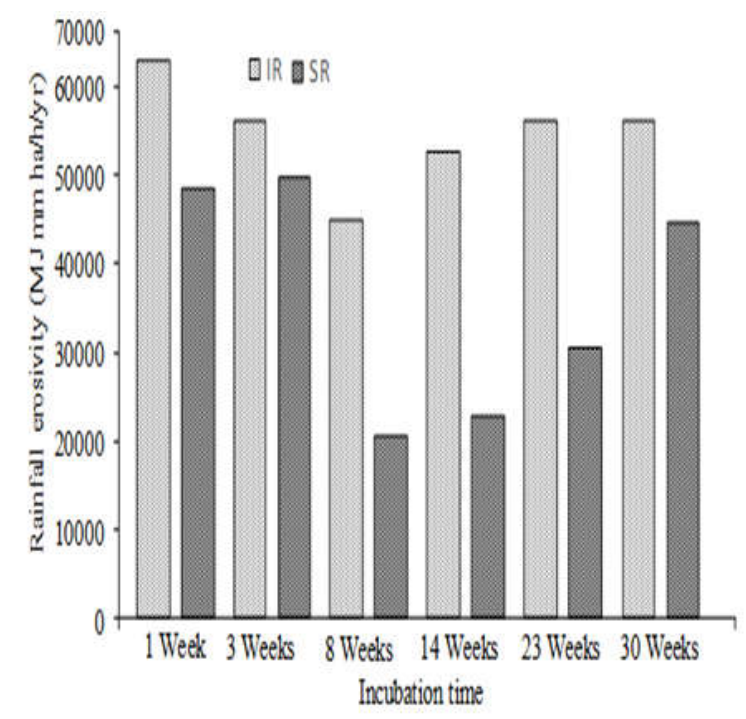

Fig 4. Rainfall erosivity per incubation time under intermittent rainstorm and single rainstorm

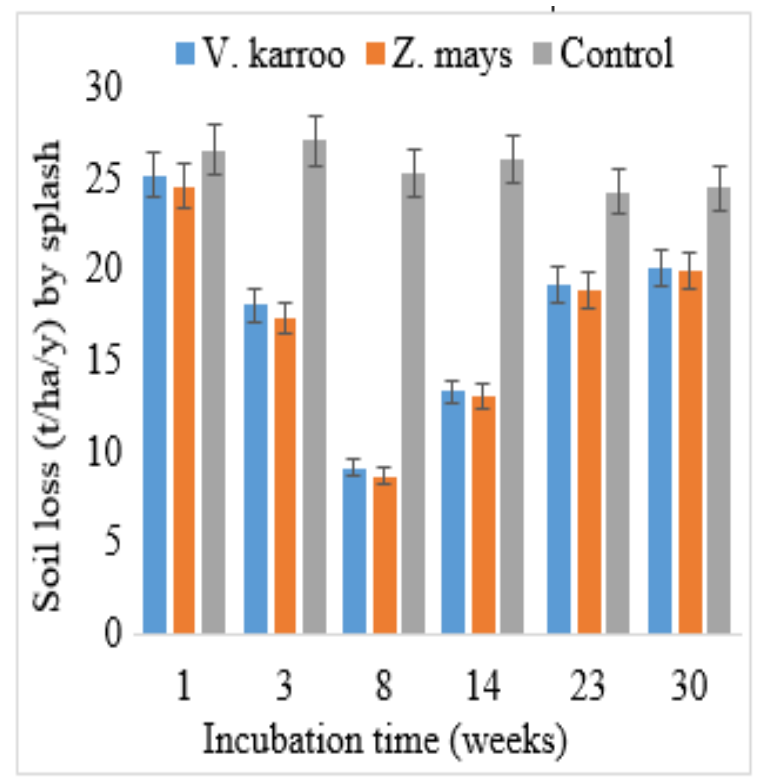

Fig 5. Effects of litter source and incubation time on soil loss (t/ha/y) by splash

Evolution of soil loss (t/ha/yr) during incubation: Area coverage (\%) of any soil loss range was relatively larger under IR than SR as from week 1 to 30 of incubation (Table 4). At week 0 (prior incubation), the area of any soil loss range was the same under both IR and SR. This could be that the litter effect on soil particle detachment due to raindrop impacts was still negligible. 
Table 4. Summary statistics of the soil loss ( $\mathrm{t} / \mathrm{ha} / \mathrm{yr})$ during the incubation period

\begin{tabular}{llllll|lllll}
\hline Time & \multicolumn{4}{c}{ Soil loss coverage (\%) under SR } & \multicolumn{5}{c}{ Soil loss coverage (\%) under IR } \\
(Weeks) & $<\mathbf{5}$ & $\mathbf{5 - 1 0}$ & $\mathbf{1 0 - 1 5}$ & $\mathbf{1 5 - 2 0}$ & $\mathbf{>} \mathbf{2 0}$ & \multicolumn{1}{c}{$\mathbf{5}-\mathbf{1 0}$} & $\mathbf{1 0 - 1 5}$ & $\mathbf{1 5 - 2 0}$ & $>\mathbf{2 0}$ \\
\hline $\mathbf{0}$ & 70.0 & 14.2 & 9.5 & 4.8 & 1.5 & 70.0 & 14.2 & 9.5 & 4.8 & 1.5 \\
$\mathbf{1}$ & 86.0 & 6.0 & 0.0 & 0.2 & 7.8 & 0.6 & 86.0 & 3.8 & 1.5 & 8.1 \\
$\mathbf{3}$ & 70.0 & 19.5 & 0.7 & 1.8 & 8.0 & 4.0 & 76.0 & 1.0 & 11.2 & 7.9 \\
$\mathbf{8}$ & 90.0 & 0.3 & 2.5 & 0.1 & 7.1 & 88.0 & 3.1 & 1.1 & 0.2 & 7.6 \\
$\mathbf{1 4}$ & 91.5 & 1.4 & 0.1 & 0.1 & 7.0 & 1.9 & 90.0 & 0.1 & 0.2 & 7.8 \\
$\mathbf{2 3}$ & 89.2 & 2.1 & 0.3 & 2.2 & 6.2 & 2.2 & 90.2 & 0.7 & 0.6 & 6.4 \\
$\mathbf{3 0}$ & 87.9 & 3.1 & 1.1 & 0.2 & 7.6 & 1.3 & 88.2 & 2.5 & 0.2 & 7.8 \\
\hline LSD $_{(\mathbf{0 . 0 5})}$ & 3.2 & 2.5 & 0.6 & 1.2 & 0.7 & 3.1 & 2.7 & 2.1 & 1.3 & 0.8 \\
\hline \multicolumn{8}{c}{ SR - Single rainstorm and IR - Intermittent rainstorm }
\end{tabular}

At week 1 after incubation, $86 \%$ of the total area had soil loss of 5-10 $\mathrm{t}^{-1} \mathrm{ha}^{-1} \mathrm{yr}^{-1}$ and $<5 \mathrm{t}^{-1} \mathrm{ha}^{-1} \mathrm{yr}^{-1}$ under IR and SR respectively (Figure 6). About $0.23 \%$ and $1.46 \%$ of the total area lost soil between $15-20 \mathrm{t}^{-1} \mathrm{ha}^{-1}$ $\mathrm{yr}^{-1}$ under SR and IR respectively (Figure 6). Extremely high erosion rates $\left(>20 \mathrm{t}^{-1} \mathrm{ha}^{-1} \mathrm{yr}^{-1}\right)$ covered a proportion area of $7.8 \%$ under SR and $8.1 \%$ under IR (Figure 6) but contributed highest $(75.9 \%)$ and $(77.7 \%)$ to the total estimated soil loss respectively.
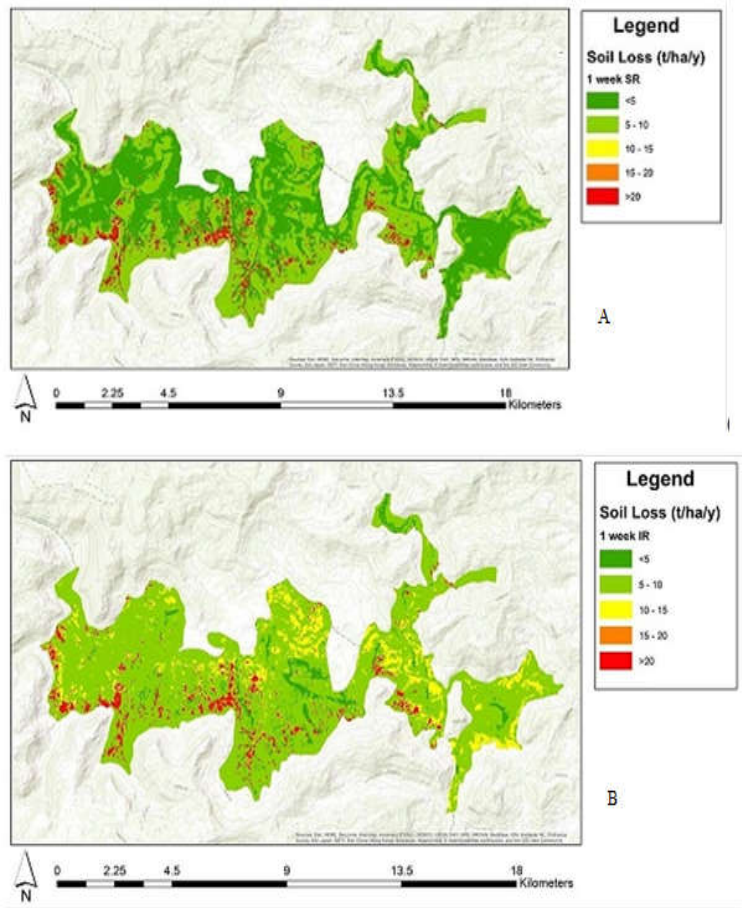

Fig 6. Spatial distribution of classified soil erosion risk after 1 week of incubation (a) under single rainstorm (SR), (b) under intermittent rainstorm (IR)

Largest $(88 \%)$ and $(90 \%)$ proportions of the area experienced low soil loss $\left(<5 \mathrm{t}^{-1} \mathrm{ha}^{-1} \mathrm{yr}^{-1}\right)$ at 8 weeks after incubation under IR and SR respectively (Figure 7). Smallest portions of total area, $0.23 \%$ and $0.09 \%$ had soil loss of 15-20 $\mathrm{t}^{-1} \mathrm{ha}^{-1} \mathrm{yr}^{-1}$ under IR and SR respectively (Figure 7). Extremely high erosion rates $\left(>20 \mathrm{t}^{-1} \mathrm{ha}^{-1} \mathrm{yr}^{-1}\right)$ were experienced on $7.6 \%$ and $7.1 \%$ of the total area (Figure 7) which contributed highest
(77.2\%) and (68.6\%) to the total estimated soil loss under IR and SR respectively. At 14 weeks of incubation, largest area (90\%) experienced soil loss of 5-10 $\mathrm{t}^{-1} \mathrm{ha}^{-1} \mathrm{yr}^{-1}$ under IR and (91.5\%) had soil loss of $<5 \mathrm{t}^{-1} \mathrm{ha}^{-1} \mathrm{yr}^{-1}$ under SR. Smallest portions of the total area, $0.15 \%$ and $0.06 \%$ had soil loss of $15-20 \mathrm{t}^{-1} \mathrm{ha}^{-1}$ $\mathrm{yr}^{-1}$ under IR and SR respectively (Figure 8).
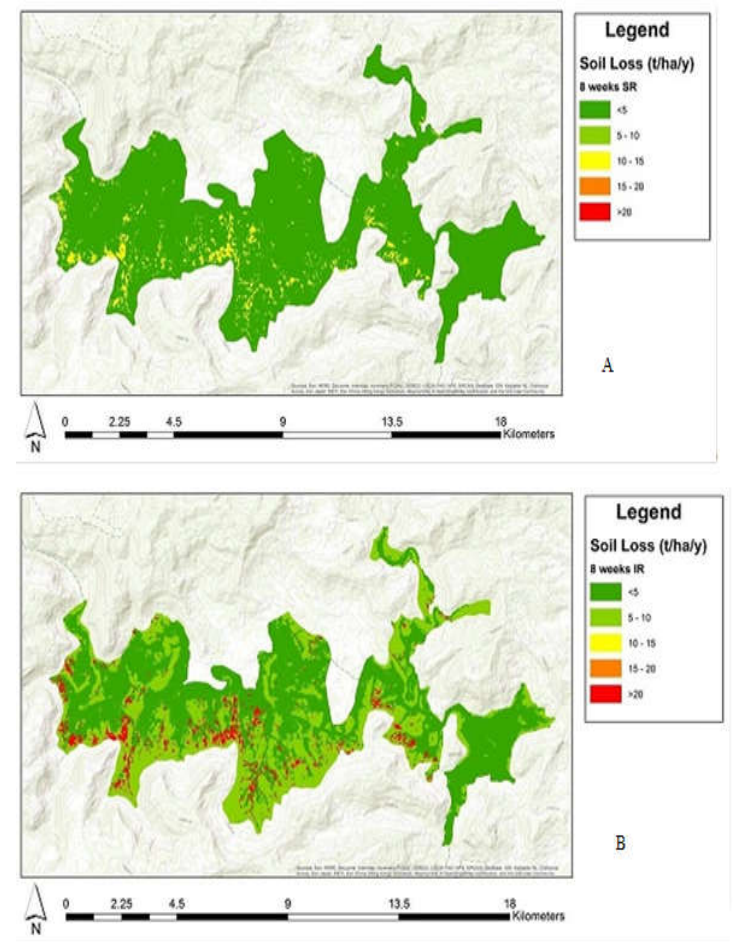

Fig 7. Spatial distribution of classified soil erosion risk zones after 8 weeks of incubation (a) under single rainstorm (SR), (b) under intermittent rainstorm (IR)

Extremely high erosion rates $\left(>20 \mathrm{t}^{-1} \mathrm{ha}^{-1} \mathrm{yr}^{-1}\right)$ covered $7.8 \%$ and $7.0 \%$ of the total area (Figure 8 ) but contributed highest $(78.3 \%)$ and $(71.1 \%)$ to the total estimated soil loss under IR and SR respectively. At 30 weeks of incubation, most $(88.2 \%)$ of the area experienced soil loss rates of 5-10 $\mathrm{t}^{-1} \mathrm{ha}^{-1} \mathrm{yr}^{-1}$ under IR and $87.9 \%$ of the area experienced soil loss of $<5 t^{-1}$ $\mathrm{ha}^{-1} \mathrm{yr}^{-1}$ under SR. 

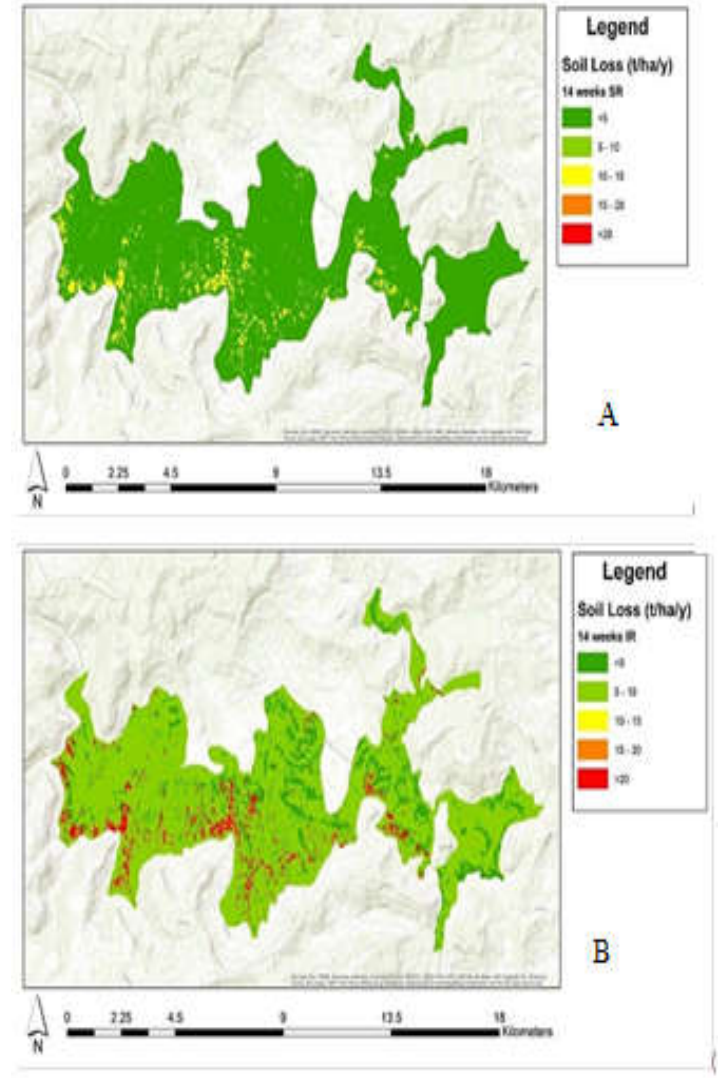

Fig 8. Spatial distribution of classified soil erosion risk zones after 14 weeks of incubation (a) under single rainstorm (SR), (b) under intermittent rainstorm (IR)

Smallest portions of the area, $0.18 \%$ and $0.24 \%$ had soil loss of 15-20 $\mathrm{t}^{-1} \mathrm{ha}^{-1} \mathrm{yr}^{-1}$ under IR and SR respectively (Figure 9). Extremely high erosion rates $\left(>20 \mathrm{t}^{-1} \mathrm{ha}^{-1} \mathrm{yr}^{-1}\right)$ covered $7.8 \%$ and $7.6 \%$ of the area (Figure 9) but contributed highest (78.5\%) and $(76.5 \%)$ to the total estimated soil loss under IR and SR respectively. The soil loss rates observed in this study are similar to Cheng et al, (2008) who found minimum values of 0.51 and maximum values of $11.72 \mathrm{t}^{-1} \mathrm{ha}^{-1} \mathrm{yr}^{-1}$ in soils with average SOC of $1.50 \%$ under the SR. The trend noted on soil loss rates agreed with previous studies which revealed that pretreating soil with organic matter can reduce splash erosion but only up to a threshold period declining thereafter (Parwada and Van Tol., 2019). In this study, the addition of organic matter reduced soil loss rates up to 8 weeks and 14 weeks after incubation under IR and SR respectively. (Figures 7 and 8). Therefore, in order to maintain the effects of OM on soil erodibility, fresh OM has to be applied after 8 weeks. The observed reduced soil loss rates during the incubation fitted within the ranges by Le Roux et al. (2008) and Cheng et al, (2008), when obtained similar the rates under field conditions.
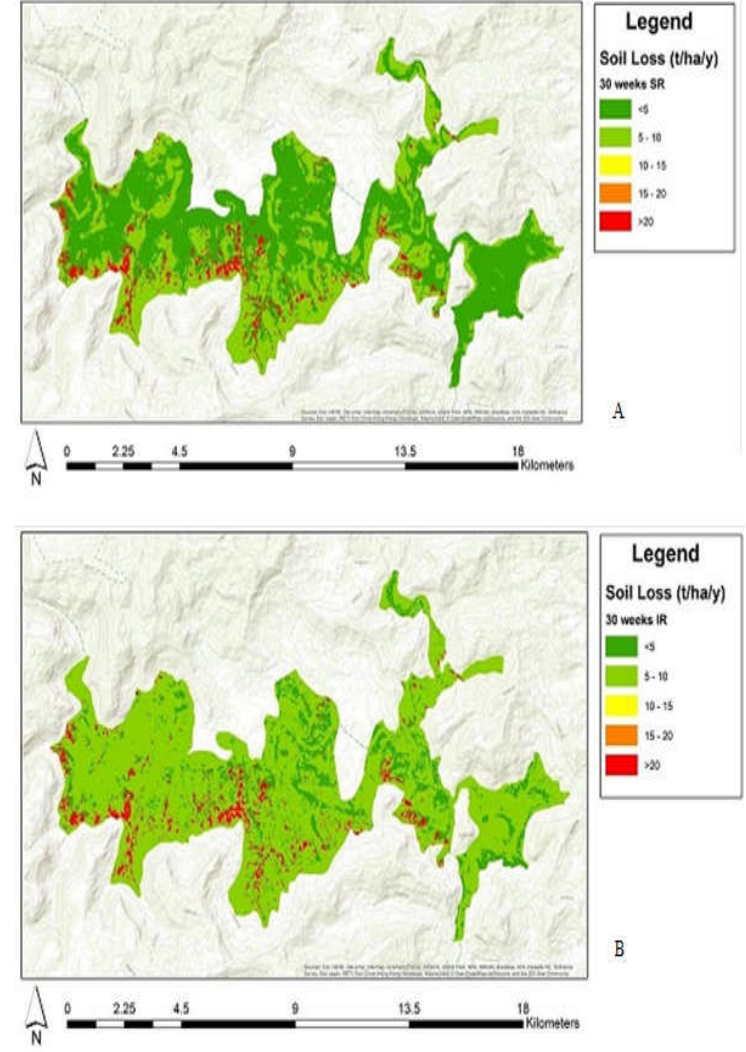

Fig 9. Spatial distribution of classified soil erosion risk zones after 30 weeks of incubation (a) under single rainstorm (SR), (b) under intermittent rainstorm (IR)

Suggesting that the results could be extrapolated for field conditions though the observed soil loss rates in this study could be lower than the actual field rates (Le Roux et al., 2008), making a comparison between the results difficult. During the incubation, micro aggregates $(<0.25 \mathrm{~mm})$ were used. Micro aggregates are more susceptible to splash erosion than the macroaggregates $(>0.25 \mathrm{~mm})$ hence the soil needed to re-form the water-stable macroaggregates $(>0.25 \mathrm{~mm})$ in order to resist the raindrops splashing effects. Therefore, a larger area showed to experienced very high erosion rates at week 1 than succeeding weeks after incubation because fewer water-stable macroaggregates had re-formed at the 1 week of incubation (Figure 3e). The added OM significantly enhanced water stable macroaggregate (WSA) reformation and this could explain the noted gradual reduction in area experiencing high-to-extremely high $\left(15-20 \mathrm{t}^{-1} \mathrm{ha}^{-1} \mathrm{yr}^{-1}\right.$ and $\left.>20 \mathrm{t}^{-1} \mathrm{ha}^{-1} \mathrm{yr}^{-1}\right)$ soil losses at 1 to 8 weeks of incubation (Figure 6 and 7). The diminishing effects of OM in re-forming the WSA as a result of decomposition caused a gradual increase in the area experiencing high-to-extremely high (15-20 $\mathrm{t}^{-}$ ${ }^{1} \mathrm{ha}^{-1} \mathrm{yr}^{-1}$ and $>20 \mathrm{t}^{-1} \mathrm{ha}^{-1} \mathrm{yr}^{-1}$ ) erosion rates observed as from 14 to 30 weeks of incubation under both SR and IR (Figure 8 and 9). 
Conclusion: The area under a specific erosion risk class was changing with the incubation time. The OM reduced the area experiencing high-to-extremely high soil loss from 3-14 weeks of incubation, thereafter the areas gradually increased. Area under high-toextremely high soil loss was reduced more under SR than IR. Basing on the rainstorms, fresh litter should be reapplied after at least 8 weeks from the initial application. The study provides an assessment of erosion dynamics and a basis for identifying conservation priorities across the proposed Ntabelanga dam catchment.

\section{REFERENCES}

Afifi. AA; Gad, AA (2011). Assessment and Mapping Areas Affected by soil Erosion and Desertification in the North Coastal Part of Egypt. Inter. J. Water Resources and Arid Environ. 1: 83-91

Arnoldus, HMJ (1980) An approximation of the rainfall factor in the Universal Soil Loss Equation. In De Boodts. M, Gabriels. D (Eds). Assessment of erosion. Wiley, Chichester. UK, pp. 127-132

Cheng, Q; Cai, Q; Ma, W (2008) Comparative study on Rain Splash Erosion of Representative Soils in China. Chin. Geogra. Sci. 18: 155-161

Department of Water Affairs (2013) Feasibility study. Mzimvubu Water Project. Newsletter 1 August

Hazelton, P; Murphy, B (2007) Interpreting soil test-What do all the numbers mean? CSIRO publishing, Collingwood, Australia

Igwe, CA; Akimigbo, FOR; Mbagwu, JSC (1995). The use of some soil aggregate indices to assess potential soil loss in soils of southeastern Nigeria. Inter. Agrophy. 9: 95-100

IUSS Working Group WRB (2015). World Reference Base for Soil Resources 2014, update 2015, International soil classification system for naming soils and creating legends for soil maps. World Soil Resources Reports No. 106. FAO, Rome.

Kay, BD; Angers, DA (2000). Soil Structure. In: Sumner. ME (Ed). Handbook of Soil Science, CRC Press, Boca Raton, FL, pp. A-229- A-276

Laker, MC (2004). Advances in soil erosion, soil conservation, land suitability evaluation and land use planning research in South Africa. South Afr. J. Plant and Soil. 21: 345-368

Land type survey staff, (1972 - 2006). Land types of South Africa: Digital map (1:250 000 scale) and soil inventory datasets. ARC-Institute for Soil, Climate and Water, Pretoria
Le Roux, JJ; Morgenthal, TL; Summer, PD; Pretorious, DJ (2008). Water erosion prediction at national scale for South Africa. Water SA. 34: 305-314

Martin, C; Pohl, M; Alewell, C; Korner, C; Rixen, C (2010). Interrill erosion at disturbed alpine sites: Effects of plant functional diversity and vegetation cover. Basic Appl. Ecol. 11: 619-626

Minasny, B; Mcbratney, AB (2006). A conditioned Latin hypercube method for sampling in the presence of ancillary information. Comput. Geosci. 32: 1378-1388

Parwada, C; Van Tol, J (2016). Soil properties influencing erodibility of soils in the Ntabelanga area, Eastern Cape Province, South Africa. Acta Agr Sca, Section B-Soil and Plant Sci. 67: 67-76

Parwada, C; Van Tol, J (2019). Influence of litter source on soil splash rates and organic carbon loss in different soil horizons. Water SA. 45(1):12-19

Renard, KG; Foster, GR; Weessies, GA; McCool, DK (1997). Predicting soil erosion by water: a guide to conservation planning with the Revised Universal Soil Loss Equation (RUSLE). Agriculture Handbook No. 703. In: Yoder DC, editor. U.S. Department of Agriculture

Reynolds, WD; Drury, CF; Yang, XM; Fox, CA; Tan, CS; Zhang, TQ (2007). Land management effects on the near-surface physical quality of clay loam soils. Soil Till. Res. 96: 316-330

Rosewell, CJ (1993). SOILLOSS- a program to assist in the selection of the management practices to reduce erosion. Soil Conservation Service of New South Wales, Technical Handbook No.11.2 ${ }^{\text {nd }}$ edition

Soil Classification Working Group (1991). Soil Classification. A Taxonomic System for South Africa. Department of Agricultural Development, Pretoria, South Africa

Van Tol, JJ; Akpan, W; Kanuka, G; Ngesi, S; Lange, D (2014). Soil erosion and dam dividends: Science facts and rural 'fiction' around the Ntabelanga dam, Eastern Cape, South Africa. SA. Geo. J. 98: 169-181

Van Zijl, GM; Ellis, F; Rozanov, A (2014). Understanding the combined effect of soil properties on gully erosion using quantile regression. SA. J. Plant and Soil. 31: 163-172 